\title{
PERANAN PARIWISATA BAHARI DALAM PEMBERDAYAAN DAN PENINGKATAN TARAF EKONOMI MASYARAKAT LOKAL DI DESA LES KECAMATAN TEJAKULA KABUPATEN BULELENG
}

\author{
Ni Ketut Mareni ${ }^{1}$, A.A.Istri M. Septiviari ${ }^{2}$ \\ ${ }^{1}$ Program Studi Manajemen Akuntansi Perhotelan, Sekolah Tinggi Pariwisata Bali, \\ niketut.mareni@yahoo.com \\ ${ }^{2}$ Program Studi Manajemen Akuntansi Perhotelan, Sekolah Tinggi Pariwisata Bali, \\ septiviari16@gmail.com
}

\begin{abstract}
ABSTRAK:
Desa les merupakan salah satu desa yang berada dalam Kecamatan Tejakula yang memiliki daya tarik wisatawan karena keindahan terumbu karang di laut yang ada didaerah tersebut. Keberlangsungan kegiatan wisata beserta operasionalnya tidak lepas dari dukungan sepenuhnya melalui pemberdayaan masyarakat desa., Namun seiring terus berkembangnya wisata bahari di Desa Les, sarana akomodasi sebagai salah satu penunjang pariwisata seperti home stay, villa, restaurant dan lainnya yang ada di Desa Les sangat minin bahkan dikatakan tidak ada.. Dampak dari pemberdayaan masyarakat local dalam kegiatan wisata bahari bagi kehidupan masyarakat Desa Les adalah; dampak ekonomi yaitu meningkatnya pendapatan masyarakat, serta meningkatnya kesejahteraan masyarakat yang ditandai dengan terpenuhinya kebutuhan masyarakat, baik kebutuhan primer, sekundr, maupun tersier. Dampak pendidikan yaitu meningkatnya tingakt pendidikan masyarakat, didapatnya pelatihan dan pendidikan dalam bidang pariwisata yang diberikan oleh pemerintah dan pihak swasta yang bertanggung jawab atas pengembangan wisata bahari di Desa Les. Dampak social budaya yaitu berkembangnya kesenian tari yang ada dan terpeliharanya bangunanbangunan pura yang ada di Desa Les karena mendapat sumbangan-sumbangan dari pemerintah maupun swasta.
\end{abstract}

Kata kunci: Peranan, Pariwisata Bahari, dan taraf ekonomi.

\section{ABSTRACT:}

Les villages is one of the villages located in the District of Tejakula who has had a tourist attraction because of the coral reefs in the sea in the area. The sustainability of tourist activities and its operations can not be separated from the full support trough the empowerment of rural communities, but with the development of nautical tourism in the village of Les. Accommodation facilities as one of the supporting tourism such as home stay,villa, restaurant and others in the village of Les wa minimal even to say no, this is one opportunity for the people of the village of Les to providing facilities such accommodation. The impact of the empowerment of local communities in marine tourism activities for the lifeof the villagers Les, are: The economic impact is rising incomes and increase in the welfare of society is marked by the need of the community, both the need of primary, secondary, and tertiary. Education inpact that rising levels of 


\section{National Conference of Creative Industry: \\ Sustainable Tourism Industry for Economic Development}

Universitas Bunda Mulia, Jakarta, 5-6 September 2018

e-ISSN No: 2622-7436

public education, the acquition of training and education in the field of tourism offered by the government and the private sector which is responsible for development of nautical tourism in the village of Les. Social inpact of culture is developing dance art and the preservation of exiting buildings of the temple in the village of Les as it gets donations from government and private parties.

\section{PENDAHULUAN}

Website Kementrian Koordinator Bidang Pembangunan Manusia dan Kebudayaan, perubahan paradigma dilakukan oleh Pemerintah Indonesia melalui perubahan pola pikir dari continental approach ke marine approach. Pemanfaatan alam bawah laut berdasarkan pernyataan dari Kementrian Koordinator Bidang Pembangunan Manusia dan Kebudayaan tersebut dilakukan dengan harapan meningkatkan kemakmuran dan kesejahteraan masyarakat. Akan tetapi, dalam pemanfaatan seumber daya alamnya sampai saat ini belum terlaksana secara optimal dan masih jauh dari tahap untuk mencapai kemakmuran dan kesejahteraan.

Perairan di Indonesia dapat dimanfaatkan dengan lebih efektif, terlebih lagi karena Indonesia merupakan negara kepulauan yang terdiri atas 17.508 pulau (baru terdaftar di Perserikatan Bangsa-Bangsa sebanyak 13.466 pulau), memiliki garis pantai sepanjang $91.181 \mathrm{~km}$, memiliki luas laut 5,8 juta $\mathrm{km}^{2}$ atau $75 \%$ dari luas wilayah Indonesia berupa lautan.

Sebagai negara kepulauan, perairan Indoensia banyak dimanfaatkan berbagai sektor terutama kelautan dan perikanan, migas, serta pariwisata. Khususnya terhadap kegiatan pariwisata, perairan Indonesia telah banyak diminati wisatawan domestik maupun mancanegara. Adapun beragam pencapaian yang diperoleh Indonesia karena keindahan alam bawah lautnya adalah :

1. Indonesia sebagai salah satu dari Scuba Earth's Top 10 Featured Destinations menurut PADI (Professional Association of Diving Instructors) yang menyatakan bahwa Indonesia memiliki wilayah dengan beragam keanekaragaman hayati seperti hiu atau makhluk laut yang tidak biasa (http://www.padi.com/blog/2014/12/17/scubaearths-top-10-featured destinations/).

2. Dive site di Derawan, Raja Ampat, Komodo, Tulamben dikategorikan sebagai salah satu dari 10 Best Dive Sites in Asia oleh CNN (Cable News Network), setelah Sipadan, Similan Island, Mergui Arch, Andaman, Kerala, Tubbataha (http://travel.cnn.com/explorations/escape/10-best-dive-sites-asia-583150).

3. Tiga dive site di Indonesia termasuk kedalam 10 terpopuler di dunia yaitu The USS Liberty Wreck (Tulamben) dan Crystal Bay (Nusa Penida) dan Taman Nasional Komodo (Batu Bolong) menurut website Divezone (http://divezone.net/best-dive-sites.htm).

4. The USS Liberty Wreck (Tulamben) menjadi salah satu dari Top 10 Dives: Best Diving in the World menurut website Scuba Travel (bersumber dari : http://www.scubatravel.co.uk/topdives.html).

Beberapa pencapaian tersebut di atas menunjukkan wisata bahari Indonesia memiliki daya saing. Bukan tidak mungkin jika pariwisata bahari menjadi salah satu aspek penting dalam pembangunan kawasan pesisir, yang akan berimbas pada meningkatnya kesejahteraan dan kemakmuran masyarakat pesisir. 
Aktivitas pilihan seperti sailing/yachting, fishing, snorkeling, parasailing, dan skiing mendapat urutan kedua yang mampu mendatangkan wisatawan sebanyak $20 \%$ $30 \%$ atau 215.800 - 324.400 wisatawan mancanegara. Aktivitas pilihan seperti diving mampu mendatangkan $10 \%-20 \%$ atau $107.800-215.600$ wisatawan mancanegara yang disajikan dalam tabel berikut :

Tabel 1.1

Distribusi Wisatawan Mancanegara pada Daya Tarik Wisata Bahari di Indonesia Tahun 2014

\begin{tabular}{|ccccc|}
\hline NO & \multicolumn{2}{c|}{ Distribusi Wisatawan Mancanegara pada Daya Tarik Wisata } \\
Bahari
\end{tabular}

Sumber : Direktorat MKKIE dan Ditjen PDP (2014) dalam Sudiarta (2015)

Desa Les merupakan salah satu desa yang berada dalam Kecamatan Tejakula yang memiliki batas teritori wilayah, yakni: sebelah utara berbatasan dengan laut Bali, sementara sebelah selatan berbatasan dengan hutan Bangli, Kecamatan Kintamani. Sebelah timur berbatasan langsung dengan Desa Penuktukan, sementara di sebelah barat berbatasan dengan Desa Tejakula, kedua desa tersebut masih di dalam satu kecamatan yang sama, yakni Kecamatan Tejakula. Beberapa desa di Kecamatan Tejakula biasanya dibatasi oleh sungai musiman yang melintas diantara dua desa.

Mata pencaharian penduduk Desa Les beraneka ragam, seperti nelayan ikan konsumsi, nelayan ikan hias, pekerja bangunan, pedagang, dan beberapa pengusaha. Namun sebagian besar terkonsentrasi pada sektor pekerjaan nonformal bertani dan berternak.

Desa Les memiliki daya tarik yang mampu mendatangkan wisatawan karena keindahan terumbu karan di laut yang ada di daerah tersebut. Sejauh ini terumbu karang tersebut telah di budidayakan sehinga menarik minat sejumlah wisatawan untuk berkunjung. Pada tahun 2012 tecatat 376 orang wisatawan yang berkunjung ke wisata bahari Desa Les (Daftar Tamu Kelompok Nelayan Mina Bhakti Soansari, 2012). 


\section{National Conference of Creative Industry: \\ Sustainable Tourism Industry for Economic Development}

Universitas Bunda Mulia, Jakarta, 5-6 September 2018 e-ISSN No: 2622-7436

Keberlangsungan kegiatan wisata beserta operasionalnya tidak lepas dari dukungan sepenuhnya melalui pemberdayaan masyarakat desa. Namun seiring terus berkembangnya wisata bahari di Desa Les, sarana akomodasi sebagai salah satu penujang pariwisata seperti home stay, villa, restaurant dan lainnya yang ada di Desa Les sangat minim bahkan bisa dikatakan tidak ada, hal ini merupakan salah satu peluang bagi masyarakat Desa Les untuk menyediakan sarana-sarana akomodasi tersebut. Oleh karena itu dalam penelitian ini peneliti ingin mengetahui bagaimana peranan pariwisata bahari dalam pemberdayaan dan peningkatan taraf ekonomi masyarakat local. di Desa Les, Kecamatan Tejakula Kabupaten Buleleng.

\section{KAJIAN PUSTAKA}

Penelitian The Role of Sport Tourism in Employment, Income and Economic Development, Homafar et al. 2011 (Journal of Hospitality Management and Tourism) mengkaji tentang peranan pariwisata berbasis olahraga. Peranan yang dimaksud dalam penelitian ini fokus terhadap peningkatan peluang kerja, peningkatan penghasilan, dan pengembangan ekonomi. Pariwisata berbasis olahraga merupakan sebuah konsep yang baru berkembang di dunia internasional dan mengalami perkembangan pesat dalam dunia industri pariwisata.

Penelitian Dampak Pengembangan Pariwisata Terhadap Karakteristik Kultural dan Struktural Masyarakat Lokal (Studi Kasus di Kawasan Wisata Bahari Lombok Barat Propinsi NTB), Sitti Hilyana, 2001 (Tesis) mengamati perubahan karakteristik kultural dan struktural setelah adanya pengembangan pariwisata di kawasan wisata bahari Lombok Barat propinsi NTB. Lombok Barat merupakan salah satu kawasan yang memiliki potensi pariwisata Indonesia. Pemerintah NTB menetapkan Lombok Barat sebagai salah satu dari 15 kawasan wisata potensial yang tertuang dalam Keputusan Gubernur No 9 tahun 1989. Tujuan baik untuk meningkatkan kondisi ekonomi kesejahteraan masyarakt lokal. Permasalahannya terletak pada kondisi masyarakat yang hingga saat ini tidak memiliki aset produktif di sektor pariwisata karena masih mendominasi manjadi karyawan. Sebab memerlukan modal yang tidak sedikit dalam sektor pariwisata. Hal ini memungkinkan masyarakat lokal semakin terpinggirkan. Maka tujuan dari penelitian adalah mengidentifikasi karakteristik masyarakat lokal dikawasan wisata bahari Kabupaten Lombok Barat.

Variabel yang diamati karakteristik masyarakat, sikap dan persepsi masyarakat dalam program pengembangan pariwisata, aspek stuktural dan aspek kultural. Aspek kultural terdiri dari orientasi budaya, dimensi moral dan etika, norma sosial dan ikatan adat istiadat. Menggunakan metode survei, transformasi kultural dijelaskan secara deskriptif sedangkan transformasi struktural dianalisis dengan uji t. Hasil penelitian ini menunjukan adanya perubahan. Secara kultural pergeseran yang terjadi tidak signifikan. Sedangkan secara struktural perubahan yang terjadi pada perubahan mata pencaharian, diversifikasi lapangan kerja dan usaha, peningkatan pendapatan, aksesibilitas pendidikan, dan sarana prasarana pelayanan publik lainnya. Berkorelasi dengan tingkat pendidikan, Hilyana (2001) menyatakan lewat tesisnya di wilayah Lombok bahwa adanya peningkatan persepsi masyarakat terhadap pendidikan karena masyarakat sadar akan konsekuensi dari tuntutan pekerjaan sektor pariwisata yang membutuhkan keahlian dan pendidikan tinggi. 


\section{National Conference of Creative Industry: \\ Sustainable Tourism Industry for Economic Development}

Universitas Bunda Mulia, Jakarta, 5-6 September 2018 e-ISSN No: 2622-7436

Yoeti (1996:117) menjelaskan bahwa pariwisata adalah lalulintas orang-orang yang meninggalkan tinggalnya untuk sementara waktu, untuk berpesiar ke tempat lain, semata-mata sebagai konsumen dari buah hasil perekonomian dan kebudayaan guna memenuhi kebutuhan hidup dan kebudayaan atau keinginan yang beranekaragam dari pribadinya.

Menurut Soekadidjo (1997:2) menjelaskan pariwisata adalah segala kegiatan dalam masyarakat yang berhubungan dengan wisatawan. Semua kegiatan pembangunan hotel, pemugaran cagar budaya, pembuatan pusat rekreasi, penyelenggaraan pekan pariwisata, penyediaan angkutan dan sebagainya semua itu dapat disebut kegiatan pariwisata sepanjang dengan kegiatan-kegiatan itu semua dapat diharapkan para wisatawan akan datang (Demartoto, 2008:18).

Pemberdayaan adalah upaya memberdayakan mengembangkan klien dari keadaan tidak atau kurang berdaya menjadi mempunyai daya) guna mencapai kehidupan yang lebih baik. Jadi pemberdayaan masyarakat adalah upaya mengembangkan mayarakat dari keadaan kurang atau tidak berdaya menjadi punya daya dengan tujuan agar masyarakat tersebut dapat mencapai / memperoleh kehidupan yang lebih baik. Payne (1997: 266) mengatakan sebagai berikut : "to help clients gain power of decision and action over their own lives by reducing the effect of sosial or personal blocks to exercising cacity and self-confidence to use power and by transferring power from the environment to clients." Artinya bahwa tujuan pemberdayaan masyarakat adalah untuk membantu masyarakat memperoleh daya untuk mengambil keputusan dan menentukan tindakan yang akan mereka lakukan yang terkait dengan diri mereka sendiri, termasuk mengurangi efek hambatan pribadi dan sosial dalam melakukan tindakan.

Shardlow (1998:32) menjelaskan bahwa pengertian mengenai pemberdayaan pada intinya membahas bagaimana individu, kelompok maupun komunitas berusaha mengkontrol kehidupan mereka sendiri dan mengusahakan untuk membentuk masa depan sesuai dengan keinginan mereka. Pemberdayaan masyarakat mengacu kepada kata empowerment, yaitu sebagai upaya untuk mengaktualisasikan potensi yang sudah dimiliki sendiri oleh masyarakat.

Jadi, pendekatan pemberdayaan masyarakat bertitik berat pada pentingnya masyarakat lokal yang mandiri sebagai suatu sistem yang mengorganisir diri mereka sendiri sehingga diharapkan dapat memberi peranan kepada individu bukan sekedar objek, tetapi justru sebagai subjek pelaku pembangunanyan ikut menentukan masa depan dan kehidupan masyarakat secara umum, (Setiana, 2005:8). Dalam kaitannya dengan masyarakat sebagai objek yang akan diberdayakan, pemberdayaan adalah upaya memberikan motivasi/dorongan kepada masyarakat agar mereka memiliki kesadaran dan kemampuan untuk menentukan sendiri apa yang harus mereka lakukan untuk mengatasi permasalahan yang mereka hadapi.

(Setiana 2005: 6). Pada intinya, pemberdayaan masyarakat bukan membuat masyarakat makin tergantung pada program-program pemberian (charity). Pemberdayaan masyarakat adalah meningkatkan kemampuan dan kemandirian masyarakat dalam meningkatkan taraf hidupnya. Pemberdayaan masyarakat bertujuan untuk meningkatkan kemampuan masyarakat guna menganalisa kondisi dan potensi serta masalah-masalah yang perlu diatasi. Intinya adalah melibatkan partisipasi masyarakat dalam proses pemberdayaan masyarakat. 


\section{Model Penelitian}

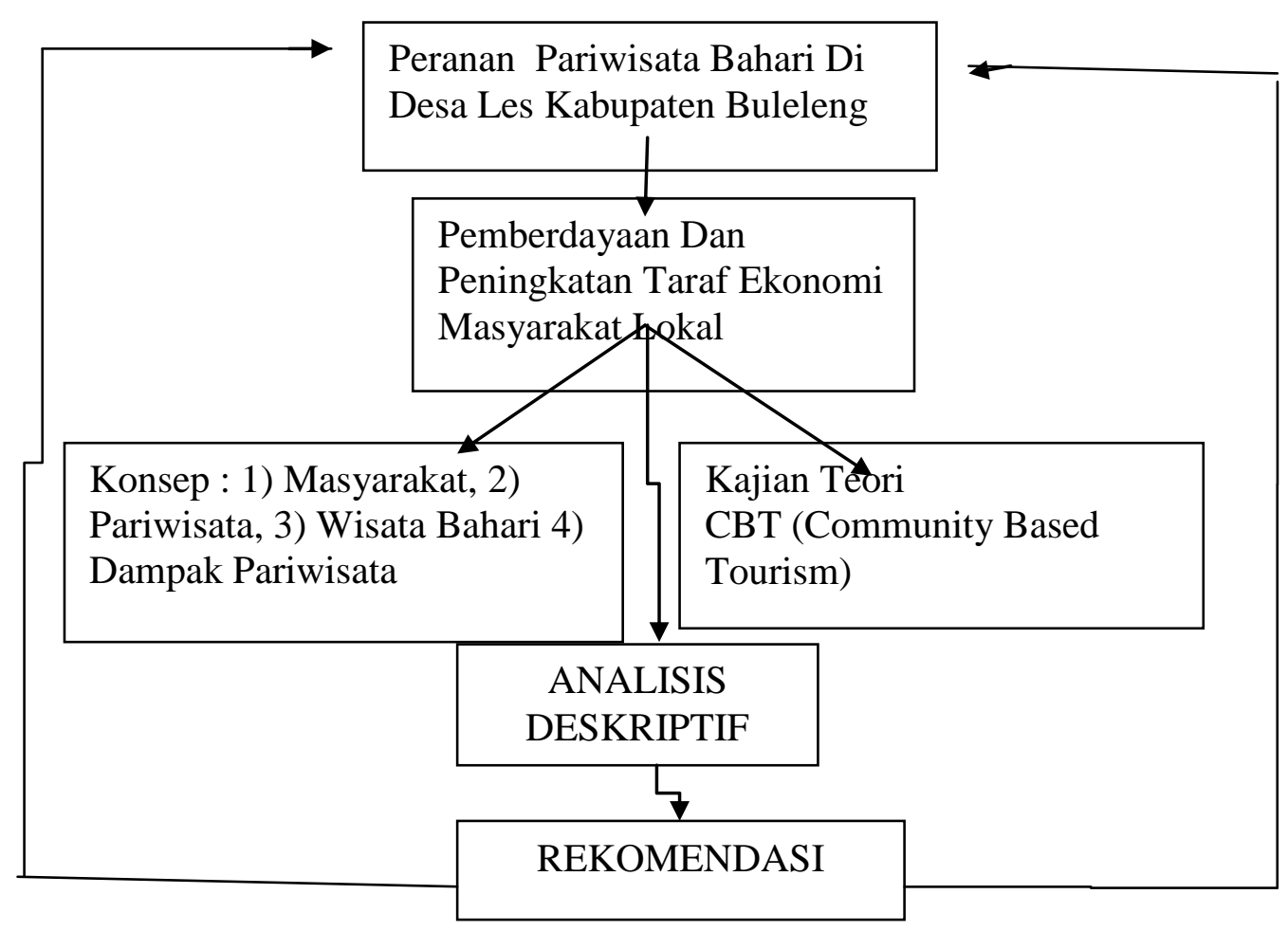

\section{Gambar 2.1 Konsep Penelitian}

\section{METODE PENELITIAN}

Teknik penentuan sampel yang digunakan adalah Purposive Sampling dimana penelitian ini tidak dilakukan pada seluruh populasi, tapi terfokus pada target. Purposive Sampling artinya bahwa penetuan sampel mempertimbangkan kriteria-kriteria tertentu yang telah dibuat terhadap obyek yang sesuai dengan tujuan penelitian dalam hal ini penelitian dilakukan pada masyarakat Desa Les, Kecamatan Tejakula, Kabupaten Buleleng. Adapun kriteria-kriteria dari masyarakat yang dijadikan sample adalah: Tinggal dan berdomisili di Desa Les, satu orang yang dianggap kepala keluarga dari satu keluarga.

Agar sampel yang diambil dalam penelitian ini dapat mewakili populasi maka dapat ditentukan jumlah sampel yang dihitung dengan menggunakan rumus Slovin (dalam Umar, 1999) sebagai berikut : Rumus Slovin untuk menentukan ukuran sampel minimal (n) jika diketahui ukuran populasi (N) pada taraf signifikasi $\alpha$ adalah:

$$
n=\frac{N}{1+N \alpha^{2}}
$$

Keterangan:

$\mathrm{n}=$ Jumlah sampel

$\mathrm{N}=$ Jumlah populasi 
$\alpha=$ Persentase kelonggaran ketidaktelitian (presesi) karena kesalahan pengambilan sampel yang masih dapat ditolerir.

Penelitian ini diketahui N sebesar 948 kepala keluarga, e ditetapkan sebesar $10 \%$. Jadi jumlah minimal sampel yang diambil oleh peneliti adalah sebesar :

$$
\begin{aligned}
& n=\frac{948}{1+948(0.1)^{2}} \\
& \quad=90,458=(\text { di bulatkan menjadi } 100 \text { Responden })
\end{aligned}
$$

Teknik pengumpulan data yang dipergunakan dalam penelitian ini adalah dengan cara melakukan observasi, wawancara, dan dokumentasi.

\section{HASIL DAN PEMBAHASAN}

Tabel 4.1

Jumlah Penduduk Desa Les Berdasarkan Struktur Mata Pencaharian

\begin{tabular}{|c|l|c|c|}
\hline No & \multicolumn{1}{|c|}{ Jenis Pekerjaan } & Jumlah (orang) & Persentase $(\%)$ \\
\hline 1 & Petani & 1381 & 19,25 \\
\hline 2 & Buruh Tani & 353 & 4,98 \\
\hline 3 & Pegawai Negri Sipil & 80 & 1,05 \\
\hline 4 & Pengerajin Industri Rumah Tangga & 41 & 0,53 \\
\hline 5 & Pedagang keliling & 33 & 0,43 \\
\hline 6 & Peternak & 1024 & 13,30 \\
\hline 7 & Nelayan & 115 & 1,49 \\
\hline 8 & Pembantu Rumah Tangga & 65 & 0,86 \\
\hline 9 & Montir & 8 & 0,10 \\
\hline 10 & Angkatan : TNI dan Polri & 8 & 0,10 \\
\hline 11 & Pensiunan & 18 & 0,24 \\
\hline 12 & Pengusaha & 15 & 0,20 \\
\hline 13 & Dosen & 1 & 0,01 \\
\hline 14 & Karyawan & 667 & 8,92 \\
\hline 15 & Tanpa Mata Pencaharian & 3670 & 51,46 \\
& Pengangguran) & & $\mathbf{1 0 0 , 0 0}$ \\
\hline
\end{tabular}

Sumber: Profil Desa Les (2015)

Tabel 4.1 menunjukan bahwa sebagian besar penduduk Desa Les bekerja sebagai petani dengan persentase sebesar 19,25\%, buruh tani (4,98\%), peternak sebesar 13,30\%, karyawan perusahaan swasta sebesar 8,785 , dan nelayan $1,49 \%$

Saat penelitian ini dilakukan, kegiatan wisata bahari dan budidaya terumbu karang lebih banyak berjalan karena adanya bantuan dari pihak swasta, dimana ada satu perusahaan yang bergerak di bidang budidaya terumbu karang memberikan pendanaan untuk pelestarian dan budidaya terumbu karang, sekaligus memberikan bantuan alat-alat menyelam. Sarana bantuan tersebut yang oleh masyarakat nelayan di Desa Les dimanfaatkan untuk melakukan kegiatan wisata bahari. Masyarakat yang diberdayakan ini lebih banyak mereka yang berprofesi sebagai nelayan karena dianggap mereka yang bersentuhan langsung dengan kegiatan wisata bahari ini. Saat ini pemerintah Desa Les sedang dalam proses pembentukan kelompok sadar wisata (Darwis), dimana dengan pembentukan kelompok ini diharapkan masyarakat Desa Les lebih memahami kegiatan 
Pariwisata yang nantinya mampu membawa mereka terlibat secara langsung dengan kegiatan pariwisata termasuk wisata bahari yang ada di desa mereka.

\section{Gambar 4.12 Kegiatan Penanaman dan Perawatan Terumbu Karang}

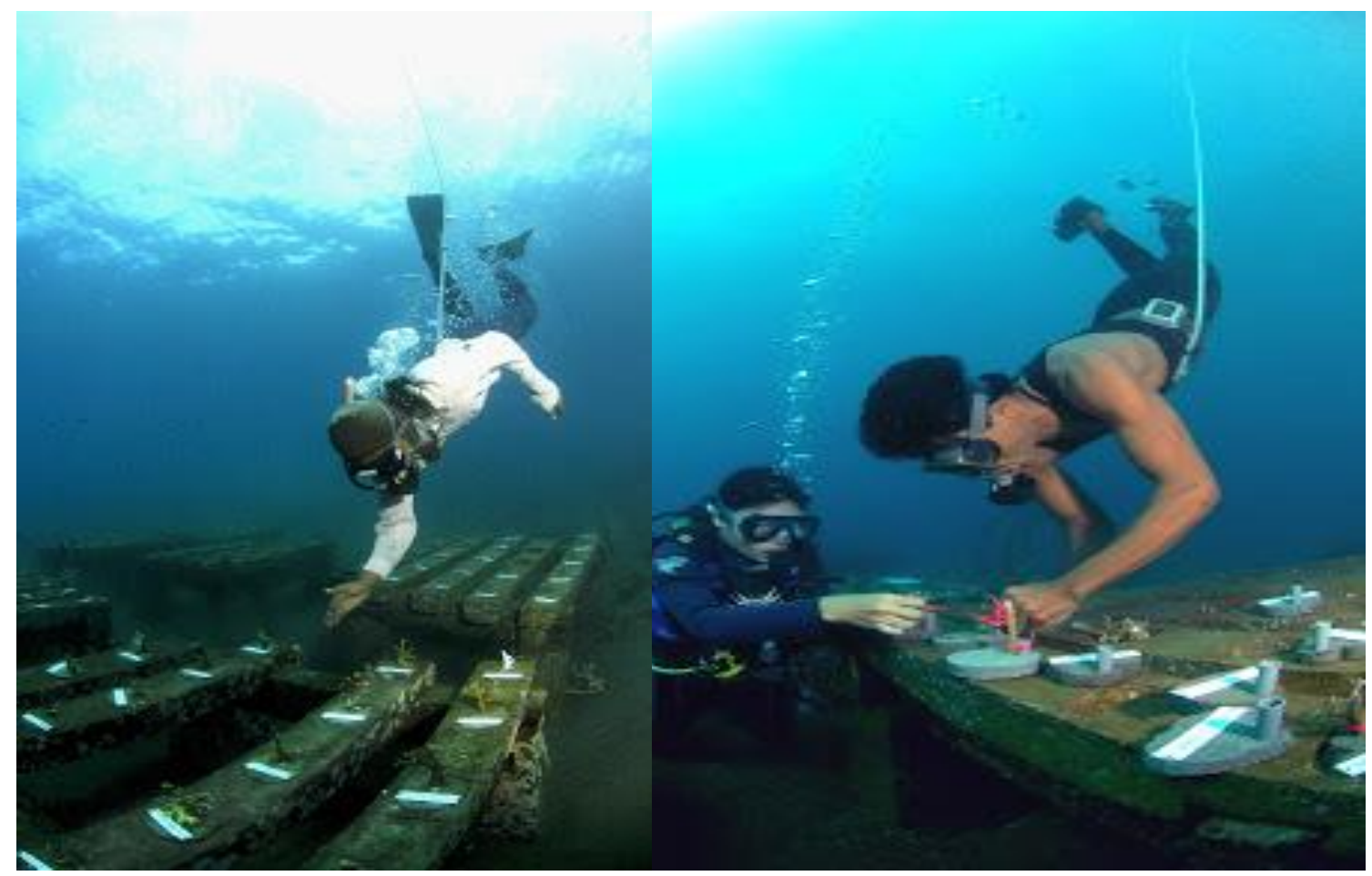

Sumber: Kelompok Nelayan Mina Bhakti Soansari, 2013

Gambar 4.12 adalah salah satu bentuk kegiatan penanaman dan perawatan terumbu karang yang dilakukan oleh masyarakat Desa Les. Gambar ini juga menunjukkan mulai sadarnya masyarakat akan pentingnya menjaga kelestarian alam.

\section{Dampak Kegiatan Wisata Bahari Bagi Kehidupan Masyarakat Desa Les}

\section{Aspek Ekonomi}

Dampak ekonomi dari pengembangan pariwisata terhadap masyarakat dapat diukur dari beberapa aspek, diantaranya: 1). Tingkat pendapatan, 2). Jenis mata pencaharian penduduk, dan 3). Tingkat kesejahteraan masyarakat yang dilihat dari kemampuan masyarakat dalam pemenuhan kebutuhan primer, sekunder, dan tersier.

\section{Tingkat Perubahan Pendapatan Masyarakat Desa Les Tahun 2015}

\begin{tabular}{|c|c|c|c|c|}
\hline No & $\begin{array}{l}\text { Jenis pekerjaan } \\
\text { sebelum adanya } \\
\text { wisata bahari }\end{array}$ & $\begin{array}{lr}\text { Jenis } & \text { pekerjaan } \\
\text { tambahan } & \text { setelah } \\
\text { adanya } & \text { wisata } \\
\text { bahari } & \end{array}$ & $\begin{array}{l}\text { Tingkat pendapatan } \\
\text { sebelum } \\
\text { wisata bahari }\end{array}$ & $\begin{array}{l}\text { Tingkat } \\
\text { pendapatan } \\
\text { setelah adanya } \\
\text { wisata bahari }\end{array}$ \\
\hline $\begin{array}{l}1 . \\
2 . \\
3 . \\
4 .\end{array}$ & $\begin{array}{l}\text { Petani } \\
\text { Nelayan } \\
\text { Petani } \\
\text { Nelayan }\end{array}$ & $\begin{array}{l}\text { Petani dan ternak } \\
\text { Ternak dan Petani } \\
\text { Dagang } \\
\text { Pramuwisata }\end{array}$ & $\begin{array}{l}1.000 .000 / \mathrm{bln} \\
1.000 .000 / \mathrm{bln} \\
1.000 .000 / \mathrm{bln} \\
1.000 .000 / \mathrm{bln}\end{array}$ & $\begin{array}{l}1.500 .000 / \mathrm{bln} \\
2.000 .000 / \mathrm{bln} \\
1.500 .000 / \mathrm{bln} \\
1.500 .000 / \mathrm{bln}\end{array}$ \\
\hline
\end{tabular}

Sumber: Data Olahan Penelitian 2015 
Hasil wawancara dan penyebaran kuisioner terhadap masyarakat Desa Les, dapat di ketahui bahwa telah terjadi tingkat pendapatan masyarakat akibat adanya wisata bahari. Penulis juga melakukan wawancara kepada Kepala Desa, menyebutkan sekitar $50 \%$ dari masyarakat yang tadinya berprofesi sebagai petani dan nelayan mendapat pekerjaan tambahan yaitu peternak dan petani. Pada tabel 4.2 di atas dapat dilihat bahwa, pendapatan masyarakat sebelum adanya wisata bahari dengan setelah adanya wisata bahari. Masyarakat yang berprofesi sebagai petani biasanya mendapatkan penghasilan Rp. 1.000.000/bln sebelum adanya wisata bahari kini masyarakat tersebut bisa mendapatkan penghasilan Rp. $1.500 .000-2.000 .000 /$ bln setelah adanya wisata bahari di desa mereka.

Pemberdayaan masyarakat di Desa Les maka secara tidak langsung berdampak terhadap perubahan tingkat pendapatan masyarakat Desa Les, maka secara umum juga tingkat kesejateraan masyarakat meningkat, hal ini dibuktikan dengan terpenuhinya kebutuhan sekunder masyarakat seperti televisi, radio, alat komunikasi atau telepon, dan kendaraan bermotor.

\section{Aspek Pendidikan}

Tabel 4.3 Tingkat Pendidikan Msyarakat Desa les, Jumlah, dan Persentase Masyarakat yang Melaksanakan Pendidikan Tahun 2012

\begin{tabular}{|l|l|c|c|c|c|c|}
\hline No & \multicolumn{1}{|c|}{ Tingkat Pendidikan } & $\begin{array}{c}\text { Th. } \\
2000- \\
2005\end{array}$ & $\begin{array}{c}\text { Persentase } \\
\text { Th. } \\
2000-2005\end{array}$ & $\begin{array}{c}\text { Th. } \\
2006- \\
2012\end{array}$ & $\begin{array}{c}\text { Persentase } \\
\text { Th. } \\
2006-2012\end{array}$ & $\begin{array}{c}\text { Perubahan } \\
\text { Tingkat } \\
\text { Pendidikan }\end{array}$ \\
\hline 1. & Tamat Perguruan Tinggi & 6 & $0.1 \%$ & 71 & $0.67 \%$ & $0.57 \%$ \\
2. & Tamat SMA & 131 & $2.11 \%$ & 765 & $10.22 \%$ & $8.11 \%$ \\
3. & Tamat SMP & 381 & $6.14 \%$ & 883 & $11.37 \%$ & $5.23 \%$ \\
4. & Kejar Paket A tingkat SMP & 0 & $0 \%$ & 72 & $0.71 \%$ & $0.71 \%$ \\
5. & Tamat SD & 4367 & $70.39 \%$ & 4681 & $63.94 \%$ & $-6.45 \%$ \\
6. & Kejar Paket A tingkat SD & 0 & $0 \%$ & 45 & $0.34 \%$ & $0.34 \%$ \\
7. & Tidak Tamat SD & 360 & $5.80 \%$ & 240 & $3.02 \%$ & $-2.78 \%$ \\
8. & Tidak Sekolah & 959 & $15.46 \%$ & 692 & $9.22 \%$ & $-6.24 \%$ \\
\hline
\end{tabular}

Sumber: Data Olahan Penelitian 2015

Tabel 4.3 dapat dilihat tingkat pendidikan masyarakat Desa Les dari tahun 2000 hingga tahun 2012 mengalami peningkatan yang cukup drastis. Masyarakat yang tamat Perguruan tinggi mengalami peningkatan sebanyak $0.57 \%$ yaitu dari $0.1 \%$ menjadi $0.67 \%$. Tamat SMA mengalami peningkatan sebanyak $8.11 \%$, yaitu dari $2.11 \%$ menjadi $10.22 \%$. Tamat SMP mengalami peningkatan sebanyak $5.23 \%$, yaitu dari $6.14 \%$ menjadi $11.37 \%$. Kejar paket A yang mengikuti ujian persamaan tingkat SMP diikuti oleh masyarakat sebanyak $0,44 \%$. Tamat SD mengalami perubahan sebanyak $-6.45 \%$, yaitu dari $70.39 \%$ menjadi $63.94 \%$. Kejar paket A yang mengikuti ujian persamaan tingkat SD diikuti oleh masyarakat sebanyak $0.25 \%$. Sedangkan untuk yang tidak tamat SD dan tidak bersekolah mengalami penurunan sebanyak masing-masing $2.78 \%$ dan 6.24\%. Dengan demikian dapat disimpulkan bahwa, dengan adanya pengembangan wisata bahari di Desa Les telah meningkatkan tingkat pendidikan masyarakat Desa Les.

\section{Aspek Sosial Budaya}




\section{National Conference of Creative Industry: \\ Sustainable Tourism Industry for Economic Development}

Universitas Bunda Mulia, Jakarta, 5-6 September 2018

e-ISSN No: 2622-7436

Pemberdayaan masyarakat lokal dalam kegiatan wisata bahari di Desa Les juga secara tidak langsung dapat mempengaruhi aspek sosial budaya masyarakat setempat.. Pemerintah yang dalam hal ini berperan sebagai pihak yang bertanggung jawab dan pihak-pihak yang ikut berperan dalam pengembangan wisata bahari di Desa Les telah memberikan banyak sumbangan, yaitu:

a. Bahan-bahan bangunan untuk pembangunan pura.

b. Bahan-bahan bangunan yang digunakan untuk pembangunan balai desa yang digunakan untuk melaksanakan kegiatan yang berhubungan dengan wisata bahari atau untuk keperluan masyarakat Desa Les.

c. Sumbangan rutin dari hasil pengelolaan wisata bahari yang dipergunakan sebagai kas desa.

d. Sumbangan sukarela untuk pelaksanaan upacara besar di Desa.

\section{Keuntungan Masyarakat dari Kegiatan Pariwisata Bahari di Desa Les}

Perkembangan wisata bahari di Desa Les mulai memberi keuntungan bagi masyarakat berupa keuntungan ekonomis dan non ekonomis. Bedasarkan hasil penelitian sebanyak 30\% masyarakat menyatakan bahwa mereka merasa keuntungan dari wisata bahari tidak seluruhnya berdampak langsung kepada masyarakat. Secara ekonomi, keuntungan dirasakan oleh masyarakat yang langsung bekerja di bidang wisata bahari sebagai pemandu maupun mereka yang bekerja di pembudidayaan terumbu karang. Selain mereka yang terlibat langsung, keuntungan juga diperoleh oleh para nelayan khususnya nelayan ikan hias.

Bagi para pemandu kegiatan wisata diving dan snorkeling, mereka mendapat jasa dari wisatawan sebanyak Rp. 150.000,00 untuk setiap pemandu dimana seorang pemandu dapat memandu maksimal dua orang wisatawan dengan penyelaman maksimal dua kali, selain biaya yang langsung diberikan kepada pemandu, wisatawan juga membayar biaya peralatan menyelam dimana untuk masing-masing wisatawan membayar Rp. 250.000,00 untuk dua kali menyelam. Biaya ini dibayarkan kepada kelompok nelayan ikan hias sebagai pengelola kegiatan. Biaya peralatan ini nantinya dimanfaatkan oleh kelompok untuk membiayai kebutuhan kelompok, memajukan kegiatan penjualan ikan hias, dan membantu anggota yang kurang dana dalam kegiatan menangkap ikan hias. Dana ini dimanfaatkan untuk membangun bangunan untuk kelompok dan pembelian peralatan menangkap ikan hias yang dapat dipergunakan oleh setiap anggota.

Kelompok nelayan ikan hias Mina Bhakti Soansari juga menjadi organisasi yang bertanggung jawab dalam kegiatan pembudidayaan terumbu karang, dimana dalam kegiatan ini juga mereka bekerja sama dengan pihak swasta. Penduduk miskin yang bekerja sebagai teknisi mendapat kompensasi berupa gaji bulanan, dimana setiap bulan mereka dibayar Rp. 700.000,00, sedangkan tenaga kerja di bidang menejemen dan keuangan mendapat gaji setiap bulan sebesar Rp. 1.000.000,00.

Selain pendapatan yang diterima oleh mereka yang bekerja langsung dibidang wisata bahari, keuntungan secara ekonomis juga diterima oleh para nelayan, khususnya nelayan ikan hias dengan kondisi terumbu karang yang semakin baik, sehingga penghasilan nelayan ikan hias menjadi lebih tinggi. Jika pada masa lalu penangkapan masih dilakukan dengan menggunakan potassium, yang berakibat pada rusaknya karang dan ikan-ikan yang ditangkap tidak seluruhnya dalam kondisi sehat dan sesuai dengan kriteria pembeli. Ikan-ikan yang ditangkap menggunakan potassium ketika akan dijual banyak yang mati, terluka, dan keracunan. Keberadaan terumbu karang yang semakin 


\section{National Conference of Creative Industry: \\ Sustainable Tourism Industry for Economic Development}

Universitas Bunda Mulia, Jakarta, 5-6 September 2018

e-ISSN No: 2622-7436

membaik menyebabkan populasi ikan hias diperairan Desa Les semakin banyak dan beragam. Kondisi ini memudahkan nelayan untuk menangkap ikan sesuai dengan pesanan konsumen.

Sistem penjualan ikan hias dilakukan melalui pengepul ikan hias, dimana ikan hias yang ditangkap sesuai dengan permintaan pegepul. Jadi nelayan hanya menangkap ikan jika ada permintaan. Harga ikan hias yang dijual oleh nelayan kepada pengepul berkisaran antara Rp. 3.000,00 - 5.000,00/ekor. Meskipun nelayan hanya menangkap ikan hias jika ada pesanan namu para nelayan ikan hias ini menyatakan bahwa pendapatan mereka jauh lebih baik daripada sebelumnya karena kondisi ikan yang mereka tangkap masih sehat dan sesuai persyaratan dari pengepul, sehingga harga jual menjadi lebih baik. Seperti yang tampak dalam gambar 4.15 berikut ini ikan hias yang berkumpul disekitar karang sehingga memudahkan nelayan dalam menangkapnya.

\section{Gambar 4.15 Ikan Hias yang Hidup di Terumbu Karang Desa Les}
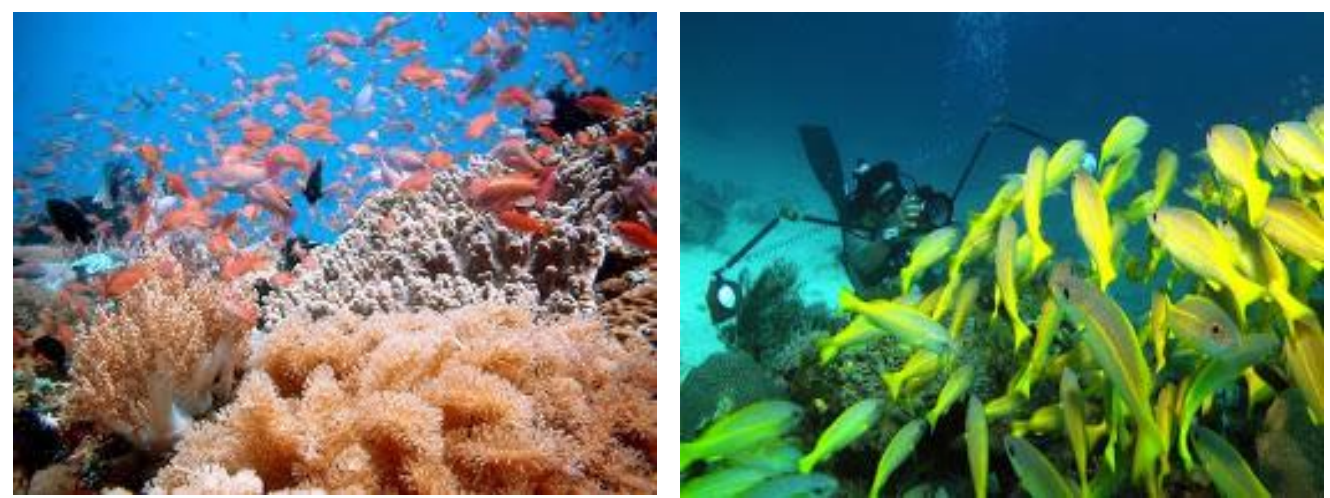

sumber: Kelompok Nelayan Mina Bhakti Soansari,2010

Gambar 4.15 adalah keanekaragaman jenis ikan hias yang menjadi salah satu mata pencaharian masyarakat untuk dijual kembali kepada konsumen. Keanekaragaman jenis ikan hias ini juga menggambarkan semakin membaiknya keadaan terumbu karang di Desa Les.

Keuntungan non ekonomis dapat pula dirasakan oleh masyarakat setempat, kegiatan nelayan Desa Les yang telah menghentikan penangkapan ikan hias menggunakan bahan kimia dan juga mereka mulai melestarikan terumbu karang, telah menarik wisatawan untuk menikmati keindahan alam bawah laut desa ini. Seiring dengan semakin baiknya kondisi alam bawah laut dan seringnya kunjungan wisatawan, beberapa stasiun televisi nasional melakukan peliputan terhadap usaha pelestarian terumbu karang ini. Adanya peliputan media massa memberikan banyak dampak positif lain bagi aktifitas wisata bahari di Desa Les.

Perkembangan wisata bahari yang ditunjang kerjasama beberapa pihak menjadikan kegiatan pelestarian terumbu karang semakin baik. Kondisi terumbu karang semakin hari semakin membaik. Dengan demikian, wisata bahari membawa dampak semakin baiknya kualitas lingkungan terutama lingkungan bawah laut Desa Les.

\section{Harapan Masyarakat Terhadap Wisata Bahari di Desa Les}

Adanya kegiatan wisata bahari yang berkembang di Desa Les secara tidak langsung dapat meningkatkan perekonomian masyarakat setempat termasuk pula memberi dampak sosial budaya yang cukup baik. Dengan adanya manfaat yang telah 


\section{National Conference of Creative Industry: \\ Sustainable Tourism Industry for Economic Development}

Universitas Bunda Mulia, Jakarta, 5-6 September 2018 e-ISSN No: 2622-7436

masyarakat lokal rasakan, timbul berbagai harapan dalam upaya mendorong lebih berkembangnya pariwisata di wilayah mereka. Seluruh anggota masyarakat yang diwakili oleh responden mengharapkan adanya perbaikan jalan, pengadaan tempat bilas, tempat parkir yang memadai, dan tempat sampah. Hal tersebut disebabkan karena jalan akses menuju ke daya tarik wisata kurang baik, sehingga kenyamanan wisatawan yang akan berkunjung ke desa tersebut terasa kurang. Selain perbaikan jalan, mereka juga sangat mengharapkan pengadaan tempat parkir karena saat ini belum ada tempat parkir sehingga para wisatawan yang datang memarkir kendaraannya dipinggir jalan. Yang tidak kalah penting adalah pengadaan tempat sampah karena saat ini tempat sampah yang tersedia sangat tidak mencukupi, sehingga sampah-sampah yang dihasilkan saat ini dibuang begitu saja.

Dengan keadaan sarana yang kurang memadai dalam pengembangan wisata bahari, maka perkembangannya menjadi sangat lamban. Masyarakat menaruh harapan utama terhadap wisata tersebut, dan masyarakat menginginkan agar suatu saat wisata bahari dapat merubah perekonomian masyarakat setempat dan mampu menjadi sumber penghasilan mereka.

\section{SIMPULAN DAN IMPLIKASI}

\section{Simpulan}

Berdasarkan hasil paparan dan analisis data pada BAB IV dapat disimpulkan sebagai berikut, pengembangan dan pengelolaan wisata bahari di Desa Les telah memberdayakan masyarakat lokal baik secara langsung maupun tidak.

1. Pemberdayaan masyarakat dalam pengembangan dan pengelolaan wisata bahari tersebut adalah:

a. Bekerja sebagai pemandu wisata dalam kegiatan wisata diving dan snorkeling.

b. Pemanfaatan sekeha atau kelompok masyarakat yang ada untuk terlibat dalam aktivitas wisata bahari di Desa Les.

c. Keikutsertaan masyarakat lokal terutama masyarakat pesisir dalam kegiatan wisata bahari di Desa Les seperti pemeliharaan kebersihan laut dan konservasi terumbu karang di Desa Les.

2. Dampak dari pemberdayaan masyarakat lokal dalam kegiatan wisata bahari bagi kehidupan masyarakat Desa Les, adalah:

a. Dampak Ekonomi

Dengan adanya pemberdayaan masyarakat dalam pengelolaan wisata bahari di Desa Les, telah memberikan dampak terhadap perekonomian masyarakat seperti: meningkatnya pendapatan masyarakat, serta meningkatnya kesejateraan masyarakat yang di tandai dengan terpenuhinya kebutuhan masyarakat, baik kebutuhan primer, sekunder, maupun tersier.

b. Dampak Pendidikan

Dengan adanya pemberdayaan masyarakat dalam pengelolaan wisata bahari di Desa les secara tidak langsung juga memberikan dampak dalam pendidikan masyarakat seperti: meningkatnya tingkat pendidikan masyarakat, didapatkannya pelatihan dan pendidikan dalam bidang pariwisata yang diberikan oleh pemerintah dan pihak swasta yang bertanggl pengembangan wisata bahari di Desa Les.

c. Dampak Sosial Budaya 


\section{National Conference of Creative Industry: \\ Sustainable Tourism Industry for Economic Development}

Universitas Bunda Mulia, Jakarta, 5-6 September 2018 e-ISSN No: 2622-7436

Dengan adanya pemberdayaan masyarakat dalam pengelolaan wisata bahari di Desa Les, secara tidak langsung juga memberikan dampak sosial budaya terhadap masyarakat, seperti: berkembang kesenian tari yang ada dan terpeliharanya bangunan-bangunan pura yang ada di Desa Les karena mendapat sumbangan-sumbangan dari pemerintah maupun pihak swasta.

\subsection{Saran}

Berikut saran yang dapat penulis sampaikan sebagai acuan dalam pemberdayaan masyarakat lokal dalam pengelolaan wisata bahari di Desa Les.

a. Agar pengembangan wisata bahari di Desa Les dapat berlangsung dengan baik, maka perlu adanya kerjasama antara pihak yang bertanggung jawab dengan masyarakat Desa Les, kerjasama itu bisa dilakukan dengan cara melakukan pemberdayaan masyarakat lokal secara efektif agar masyarakat juga merasakan dampak dari pengembangan wisata bahari di Desa Les.

b. Dalam pengembangan suatu kawasan wisata, sangat diperlukan pembinaanpembinaan dari berbagai pihak yang terkait. Dalam hal ini sangat perlu adanya pembinaan secara rutin dari pihak pemerintah dan pihak swasta yang terkait dalam bentuk penyuluhan atau penataran tentang pariwisata dan lingkungan hidup terhadap masyarakat.

c. Suatu pengembangan kawasan wisata akan lebih baik apabila sarana tersedia sesuai dengan kebutuhan. Untuk itu diharapkan pihak pemerintah dan pihak swasta yang terkait memberi perhatian khusus terhadap sarana seperti : akses jalan, tempat parkir, tempat bilas, penambahan tempat sampah, dan kebersihan air PAM.

\section{DAFTAR PUSTAKA}

Badan Pusat Statistik Provinsi Bali. 2012. Luas Wilayah dan Letak Geografis Pulau Bali dan Kabupaten/Kota Tahun 2012. http://bali.bps.go.id/table_detail.php?ed=601001\&od=1\&id=1. Diakses terakhir pada tanggal 4 maret 2014 pk 05:24 WITA.

Kates, Robert W. 2005. Environment: Science and Policy for Sustainable Development, Volume 47. http://www.heldref.org/env.php

Payne M. 1997. Modern Social Work Theory. Edisi Kedua. London: MacMillan Press Ltd.

Rifani, V. Indah. 2013. "Pemberdayaan Masyarakat Untuk Memajukan Desa Wisata Pentingsari Kecamatan Cangkringan Kabupaten Sleman Daerah IstimewaYogyakarta".http://journal.student.uny.ac.id/jurnal/artikel/2777/34/337. Diakses terakhir pada tanggal 2 Desember 2013 pk 13:00 WITA.

Soekadijo,R.G. 1997. Anatomi Parawisata. Jakarta: PT Gramedia Pustaka Utama. Yogyakarta.

Suandi, Jasminarni, Trias Novita, Evita, Suryono. 2006. "Pemberdayaan Masyarakat Melalui Pengembangan Pertanian Organik Berbasis Trikolimtan di Kota Sungai Penuh

Provinsi

Jambi”.

http://online- 
journal.unja.ac.id/index.php/jlpm/article/view/91/0. Diakses terakhir pada tanggal 29 juli 2013 pk 09:30 WITA.

Setiana, L. 2005. Pengertian Dasar Penyuluhan Pertanian. PT Gramedia, Jakarta.

Umar, Husein. 1999. Metodologi Penelitian: Aplikasi dalam Pemasaran, Jakarta: PT Gramedia Pustaka Utama.

Yoeti, Oka A. 1996. Pengantar Ilmu Pariwisata, Cetakan Pertama (Revisi). Bandung: Angkasa. 